Derleme / Review

\title{
Çocuk Sağlığı ve Hastalıkları Üzerine Yapılandırılmış Akıllı Telefon Uygulamaları ve Çocuk Sağlığına Etkileri
}

\section{Smartphone Applications Developed for Pediatrics and Their Effects on Children's Health}

\author{
Onur İşsever ${ }^{\mathrm{a}^{*}}$, Selmin Şenol ${ }^{\mathrm{b}}$, Hatice Bal Yılmaz ${ }^{\mathrm{c}}$, Figen Yardımc1 ${ }^{\mathrm{d}}$ \\ ${ }^{a}$ Uzman Hemşire, Çocuk Sağlığı ve Hastalıkları Hemşireliği, Urla Devlet Hastanesi, ORCID: https://orcid.org/0000-0001-7635-3812 \\ *iletişimden sorumlu yazar, E-mail: onurissever88@gmail.com \\ b Prof. Dr., Cocuk Sağlığı ve Hastalıkları Hemşireliği, Kütahya Sağlık Bilimleri Üniversitesi Sağlık Bilimleri Fakültesi, ORCID: https://orcid.org/0000-0003-4716-3512 \\ c Prof. Dr., Çocuk Sağlığı ve Hastalıkları Hemşireliği, Ege Üniversitesi Hemşirelik Fakültesi, ORCID: https://orcid.org/0000-0001-8015-6379 \\ ${ }^{d}$ Doç. Dr., Çocuk Sağlığı ve Hastalıkları Hemşireliği, Ege Üniversitesi Hemşirelik Fakültesi, ORCID: https://orcid.org/0000-0002-1550-985X
}

\section{ARTICLE INFO}

Article History:

Received 27.05.2021

Received in revised form 23.10 .2021

Accepted 30.10.2021

Keywords:

Smartphone Application

Child

Diseases

Health

\begin{abstract}
Use of devices like smartphones, iPads and computers, which enable children to utilize mobile technologies, increases day by day. This study has been conducted to compile original articles evaluating the smartphone applications built for paediatrics. During the study, PubMed database was searched. Within the scope of the literature survey, ten articles published with the aim of maintaining and promoting childrens' health with mobile applications were reviewed. It is safe to state that the use of mobile health applications on children is a new and limited concept. Although applications and research are limited, the common result of these shows that the use of mobile health applications by professionals, children and nurses has a promising and contributing potential for child health.
\end{abstract}

(c) 2021 Mardin Artuklu University. All rights reserved.
MAKALE BILLGILERİ

Makale Geçmişi:

Geliş Tarihi: 27.05 .2021

Revizyon Tarihi: 23.10 .202

Kabul Tarihi: 30.10 .2021

Anahtar Kelimeler:

Akıllı telefon uygulamaları

Çocuk

Hastalık

Sağlık

\section{ÖZET}

Mobil teknolojilerin çocuklar tarafından kullanımını sağlayan telefon, iPad, bilgisayarlar gün geçtikçe artmaktadır Çocukların akıllı telefon uygulamalarındaki sağlık verilerine erişim, sağlık profesyonellerinin (hekim, hemşire, diyetisyen gibi) izlem ve tedavi sonuçları konusunda katkı sağlayabilir. Araştırma; çocuk sağlığı ve hastalıkları ile ilgili yapılmıs akıllı telefon uygulamalarını ele alan orijinal makaleleri incelemek amacıyla yapılmıştır. Literatür taramasında, Pubmed veri tabanı kullanılmıştır. Literatür taraması kapsamında mobil uygulamalarla çocuk sağlığını korumayı ve geliştirmeyi hedefleyen yayınlanmış on makale incelenmiştir. Mobil sağlık uygulamalarının çocuk sağlığı üzerine kullanımının yeni ve sınırlı olduğu söylenebilir. Uygulamalar ve yürütülen araștırmalar sınırlı olmakla birlikte, bunların ortak sonucu mobil sağlık uygulamalarının profesyoneller, cocuklar ve hemsireler tarafindan kullanılmasının çocuk sağlığı için umut verici ve katkı sağlama potansiyeli olduğunu göstermektedir.

\section{Giriş}

Mobil teknolojilerin kullanımını sağlayan akıllı telefon, iPad, bilgisayar ve oyun konsollarının kullanımı gün geçtikçe artmaktadır. Bu gelişim ve yayılım sadece yetişkinleri değil küçük çocukları bile etkisi altına alarak internet ve akıllı cihazlarla tanışma yaşını düşürmüştür. Türkiye İstatistik Kurumu (TÜIK) 2017 verilerine göre Türkiye'de bilgisayar kullanma yaş ortalaması sekizdir. Cep telefonu kullanma yaşı ise ondur. TÜİK araştırmasına göre, Türkiye'de 6-15 yaş arası çocukların yüzde 60,5'i bilgisayar, yüzde 50,8'i internet, yüzde 24,3'ü cep telefonu kullanmaktadır. $\mathrm{Bu}$ veriler bilgisayar teknolojilerinin ne kadar erken yaşlarda ve ne kadar sık kullanıldığını göstermektedir (1). Amerika'da çocuk kliniğine başvuran çocuklar üzerine yapılan bir araştırmada çocuklar $\% 73$ ile $\% 84$ aralığında akı1lı telefona sahiptir. İnternete giriş için telefonu ilk kaynak olarak kullananların oranının \%57 olduğu ve günde ortalama 2,5 saatten fazla telefonla vakit geçirdikleri belirtilmiştir. Akıllı telefonlarda ortalama 15 uygulamanın mevcut olduğu ve çocukların sağlıkla ilgili uygulamalara ilgi duydukları da ifade edilmiştir. Kanada'da 
ise ergenlerinin \%80'i akıllı telefona sahiptir ve bu oranın 2020'ye kadar \%92'ye yükselmesi beklenmektedir $(2,3)$.

Literatürde bu cihazların uzun süreli kullanımlarının zararlarına yönelik araştırmaların çokluğu göze çarpsa da akıllı telefon uygulamaları ile sağlığı geliştirici, koruyucu pek çok uygulama ve bilgiye erişim de mümkündür. Mobil sağlık uygulamaları gün geçtikçe dikkat çekici hale gelmektedir. Mobil sağlık uygulamaları, akıllı telefonları çok yönlü kullanmaya imkân sağlamıştır. Cep telefonları günümüzde yalnızca arama ve mesajlaşma yani iletişim için değil bilgiye ulaşım, internette gezinme, uygulama yükleme, sosyalleşme ve oyun aracı olarak da kullanılmaktadır. Yeni ortaya çıkan iletişim teknolojileri ve interaktif uygulamalar, sağlık hizmetlerini sunmak için yeni ortamlar ve olanaklar oluşturmaktadır. Sağlık hizmeti sağlayıcılarıyla doğrudan ve hızlı bir şekilde iletişim kurmak için akıllı telefonların ve internetin kullanılması, tedavi dışı kalma riski yüksek olan çocuklar ve ergenler için sağlık yönetimini iyileştirebilir. Sağlık üzerine yapılan uygulamalar ve çalışmalar sağlığın korunması, semptom yönetimi ve geliştirilmesi açısından son derece önemlidir. Sağlık üzerine yapılandırılmış akıllı telefon uygulamaları, yüksek riskli davranışları ve ulaşım kolaylığı göz önüne alındığında, her yaştan -özellikle de ergenler- için sağlık bilgisi sunmada uygun bir yöntem olabilir (3). Bu gelişmeler ışı̆̆ında akıllı telefonlara yüklenen bireysel sağlık bilgisi ile ilgili uygulamalarda artma eğilimi gözlenmektedir. Son yıllarda elektronik tıbbi kayıtlar, kişisel sağlık kayıtları ve gerçek zamanlı karar destek sistemleri gibi bilgi teknolojileri sağlık sisteminin içine dâhil edilmeye başlanmıştır (4).

Akıllı uygulamalar ile elde edilen verilerin daha rahat ve güvenli saklama alanlarında saklanabilmesinin yanı sıra verilerin Excel ve istatistiksel veri tabanlarına kolay ve hatasız şekilde aktarım şans1 da vardır. Bu aktarım, zaman ve iş gücü tasarrufu sağlamaktadır (5). Ulusal ve küresel sağlığı geliştirmek için cep telefonu üzerinden kullanılan mobil sağlık uygulamaları giderek artmakta ve faydaları vurgulanmaktadır (6).

Çocuk sağlığı ve hastalıkları profesyonel bakım vericileri (hekim, hemşire, diyetisyen vb.) çocukların akıllı telefon uygulamalarında sağlık verilerine erişerek sağlık izlemlerini sürdürebilirler. $\mathrm{Bu}$ süreçte elde edilen veriler çocuğun sağlık bilgisi gereksinimi, sağlık eğitimi, ilaç yönetimi, semptom yönetimi, sağlığı koruma ve geliştirme konularında sağlık profesyonellerine rehberlik yapabilir. Özellikle pediatri hemşiresinin bu yeni teknolojilerle aktif iş birliği sağlaması bakım verdiği çocuklar ve bakım verici ailelerine daha hızlı ve nitelikli bakım sunma fırsatı sağlayarak yaşam kalitesinin artmasında önemli bir katkı sunacaktır.

\section{Yöntem}

Araştırma, çocuk sağlığı ve hastalıkları ile ilgili yapılmış akıllı telefon uygulamaları konusundaki orijinal makaleleri incelemek amacıyla yapılmıştır. Araştırmada PubMed veri tabanından yararlanılmıştır. Arama yapılırken İngilizce dilinde mobile application, smartphone applications, pediatri, nurse anahtar kelimeleri kullanılmıştır. Derleme kapsamında 2010-2020 yıllarındaki orijinal araştırmalar yer almıştır.

\subsection{Araştırmaya dâhil edilme kriterleri}

a) Makalelerin orijinal araştırma olması

b) 2010 ile 2020 yılları arasında yapılmış olması

c) Akıllı telefon uygulaması veya internet sitesi ile çocuk sağlığı ve hastalıkları arasında ilişki kurması

d) Çocuk sağlığına müdahalede bulunması

d) Araştırmanın Türkçe veya İngilizce yayınlanmış olması

e) Araştırma makalelerinin tam metnine ulaşılabilmesi

\subsection{Araștırmaya dâhil edilmeme kriterleri}

a) Araştırmaların derleme makalesi olması

b) Araştırmanın birden fazla veri tabanında bulunması halinde tek bir veri tabanından veriler alınmıştır.

c) Araştırma makalesinin tam metnine ulaşılamamış olması

\subsection{Araştırmaların seçimi ve araştırmaların değerlendirilmesi}

Anahtar kelimelerin ve belirlenen kriterlerin PubMed veri tabanı taranması sonucunda 29 makaleye ulaşılmıştır. Araştırmalar seçim kriterlerine göre belirlenmiştir. Değerlendirme sonucunda araştırma kriterlerine uymayan 19 makale ele alınmamıştır (8 tanımlayıcı araştırma, 2 derleme, 1 meta-analiz, 1 tam metne ulaşamama, 6 araştırma tasarımı-çalışma protokolü, 1 kapsam belirleme incelemesi). Çalışmaların seçim aşaması şekil 1'de verilmiştir

Kriterlere uygun olan 10 makale çalışmaya dâhil edilmiş ve Tablo 1 'de incelenmiştir. 


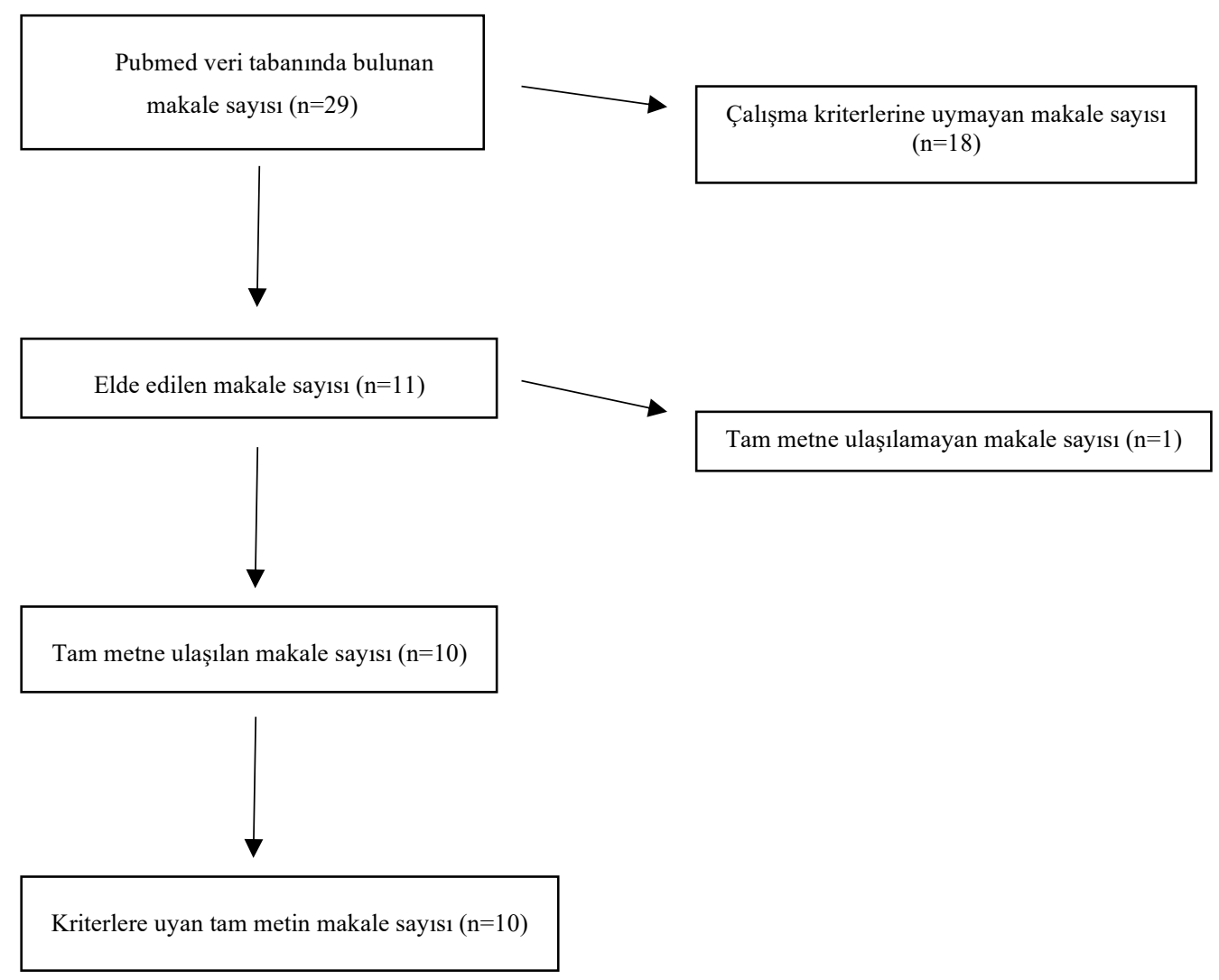

Şekil 1 - Veri Seçim Akışı

Tablo 1 - Çocuk Sağlığı ve Hastalıkları Üzerine Yapılmış Akıllı Telefon Uygulamaları Literatür Taraması Makale Tanımlayıcı Özellikleri

\begin{tabular}{|c|c|c|c|}
\hline Yazar & $\begin{array}{l}\text { Örneklem grubu ve } \\
\text { sayısı }\end{array}$ & Çalışma Dizaynı & Mobil uygulamanın kullanım amacı \\
\hline $\begin{array}{l}\text { 1.Fortier, ve ark. } \\
2016\end{array}$ & $\begin{array}{l}8-18 \text { yaş arası } \\
12 \text { çocuk }\end{array}$ & $\begin{array}{l}\text { Semptom takibi Bilişsel ve } \\
\text { davranışsal beceri eğitimi }\end{array}$ & Kanser hastalarında ağrı yönetimi ve semptom günlükleri \\
\hline $\begin{array}{l}\text { 2. Jibb ve ark. } \\
2017\end{array}$ & $\begin{array}{l}\text { 12-18 yaş arasında } \\
40 \text { ergen }\end{array}$ & $\begin{array}{l}\text { Tek gruplu (ön test/son test) } \\
\text { kontrollü çalışma }\end{array}$ & $\begin{array}{c}\text { Kanserli ergenler için gerçek zamanlı ağrı yönetimi için akıllı telefon } \\
\text { uygulaması }\end{array}$ \\
\hline $\begin{array}{l}\text { 3. Jacop, ve ark. } \\
2012\end{array}$ & $\begin{array}{l}\text { 1.Grup } 10 \text { çocuk } \\
\text { 2.Grup } 21 \text { çocuk }\end{array}$ & $\begin{array}{c}\text { Tanımlayıcı ve } \\
\text { karşılaştırmalı araştırma } \\
\end{array}$ & Orak hücreli anemi hastalarında ağrı ve semptom tanılaması \\
\hline $\begin{array}{l}\text { 4. Wantanakorn, } \\
\text { ve ark. } 2018\end{array}$ & $\begin{array}{l}\text { 5-12 yaş arasında } \\
60 \text { çocuk }\end{array}$ & $\begin{array}{l}\text { Tek kör randomize } \\
\text { kontrollü çalışama }\end{array}$ & $\begin{array}{c}\text { Kemik iliği aspirasyonu öncesi mobil uygulamanın anksiyete üzerine } \\
\text { etkisi }\end{array}$ \\
\hline $\begin{array}{l}\text { 5. Loleski, ve } \\
\text { ark. } 2018\end{array}$ & $\begin{array}{l}201 \text { katılımcı } \\
150 \text { 'si çocuk }\end{array}$ & $\begin{array}{l}\text { Uygulama geliştirme ve } \\
\text { tanımlama }\end{array}$ & Dikkat değerlendirilmesi için mobil uygulama \\
\hline $\begin{array}{l}\text { 6. Ramsey, ve } \\
\text { ark. } 2018 \\
\end{array}$ & $\begin{array}{l}13-21 \text { yaş arası } \\
35 \text { ergen }\end{array}$ & Pilot bir araştırma & Migrenli ergenlerde tedaviyi uyumu arttırma üzerine uygulama \\
\hline $\begin{array}{l}\text { 7. Roberts, ve } \\
\text { ark. } 2016\end{array}$ & $\begin{array}{l}12-16 \text { yaş arası } \\
20 \text { ergen }\end{array}$ & Tanımlayıcı & Astımlı çocuk ve ergenlerde astım yönetimi, iletişim ve tedavi \\
\hline $\begin{array}{l}\text { 8. Burbank, ve } \\
\text { ark.2015 }\end{array}$ & $\begin{array}{l}12-17 \text { yaş aras } 1 \\
18 \text { ergen }\end{array}$ & Tek kol deneysel & Astım semptomları ve uyum \\
\hline $\begin{array}{l}\text { 9. Lee, et al. } \\
2014\end{array}$ & $\begin{array}{c}1-10 \text { yaş arası } \\
120 \text { çocuk }\end{array}$ & Randomize kontrollü & Preoperatif anksiyeteyi azaltmak için akıllı telefon uygulaması \\
\hline $\begin{array}{l}\text { 10. Nayak, ve } \\
\text { ark. } 2019\end{array}$ & $\begin{array}{l}\text { Preterm } \\
300 \text { preterm }\end{array}$ & Randomize kontrollü & $\begin{array}{l}\text { Akıllı telefon tabanlı Preterm evde bakım programının pretermlerin } \\
\text { gelişimsel sonuçları üzerine etkisi }\end{array}$ \\
\hline
\end{tabular}




\section{Bulgular ve Tartışma}

Araştırmanın amacı son on yılda çocuk sağlığı ve hastalıkları üzerine yapılandırılmış, çocukların sağlıklarını etkileyen akıllı telefon uygulamalarını incelemektir. Literatür taraması kapsamında mobil uygulamalarla çocuk sağlığını korumayı ve geliştirmeyi hedefleyen yayınlanmış on makale incelenmiştir. Tarama sonrası makalelerin, randomize kontrollü, tek kör randomize kontrollü, tek gruplu kontrollü, tanımlayıcı ve pilot çalışmalara kadar geniş bir yelpazede yer aldığ görülmüştür.

Değerlendirme kapsamına alınan çalışmalarda onkoloji, hematoloji, nöroloji ve solunum sistemi ile ilgili ikişer makale tanımlandı. Çocuk cerrahisi ve yeni doğan konusunda ise birer makale vardı. $\mathrm{Bu}$ makalelerde içerik incelemesinde; ağrı ve semptom yönetimi ile ilgili üç, anksiyete ve astım ile ilgili ikişer, dikkat dağınıklığı, tedaviye uyum ve yeni doğanın taburculuk öncesi evde bakımına yönelik bilgi veren konularda birer dağılım gösterdikleri saptandı. Makaleler bu konuların alt başlı̆̆ında aşağıda ele alınmış ve tartışılmıştır.

\subsection{Ağrı değerlendirmesi}

Günümüzde mobil sağlık teknolojilerinin (akıllı telefon, tablet) ağrının yönetiminde kullanıma ilişkin literatür giderek artmaktadır (7). Özellikle kanser olgularında mobil teknolojiler yardımı ile eş zamanlı uygulanan ağrı değerlendirmesi ve yönetimi, bakım destek rehberliği tedavisi ağrı yönetimine yeni olanaklar sunmaktadır. Bunlardan biri çocuklar ve aileleri ile iletişim olanaklarını ve seçeneklerini çoğaltarak iletişim çeşitliliğini, sıklığını arttırmasıdır. Bir diğer nokta ise, elektronik değerlendirme araçlarının, sağlık bilgi verilerinin izlenmesine ve değerlendirilmesine firsat tanımasıdır (8).

Stinson ve ark. (2006) kronik artritli çocukların elektronik ağrı günlüklerini düzenli olarak kaydettiklerini belirtmiştir (9). Benzer şekilde kanserli çocukların ağrı yönetiminde ağrıyı izlemek için ağrı günlüklerinin oluşturulmasının hastanın tedavi önerilerine daha iyi uyum sağladığı belirtilmektedir. Aynı zamanda, sağlık profesyonellerine (özellikle hekim ve hemşirelere) tedaviye karar verme, bakımı yönlendirme konusunda ek veriler sağladığ 1 yönünde bazı kanıtlar sunulmuştur. ABD'de sağlık sistemindeki değişikliklerle beraber kanser hastalarının tedavi ve bakımları hastaneden çok ev ortamında yapılmaya başlanmıştır. Bununla beraber ev ortamında ağrı yönetimi konusunda yetersizlikler ortaya çıkmıştır. Akıllı telefon uygulamasında ağrının tipi, süresi ve şiddeti değerlendirilerek ağrıyla baş etme ve ağrıyı azaltma stratejileri günde iki kere olmak üzere on gün boyunca değerlendirilmiştir. Uygulama, çocukların ağrı ve semptom yönetimine yönelik farmakolojik yaklaşımların yanı sıra farmakolojik olmayan ağrı yönetimi stratejilerini öğretmek için programlanmıştır. Rehberli görüntüler, ilerleyici kas gevşemesi, diyafram solunumu, dikkati yoğunlaştırma veya dikkati başka yöne çekmek gibi 12 farklı yöntem hakkında bilgi sağlanmıştır. Artan akıllı telefon kullanımının kanser tedavisi gören çocuklar ve özellikle de ergen yaş grubunda yaşam kalitesini yükseltmede önemli bir araç olarak kullanılabileceği belirtilmiştir (9).

Jacob ve ark. (2012) orak hücre anemili çocuk grubun çalışmasında, çocukların ağrı ve semptom izlemini kendi kendilerine yaparak sağlık profesyonellerine ulaşımı kolaylaştırmayı planlanmışlardır (5). Çocuklar akıllı telefonu kullanarak e-günlük üzerine ağrı ve belirtilerini kaydederek akıllı telefon kullanımının kolaylığına, 5 dakika içinde semptomların girişini yapabildiklerine dikkat çekmişlerdir. Araştırmacılar, çocukların semptomlarının giriş kaydını da \%80'in üzerinde doğru yaptıklarını belirtmiştir. Söz konusu akıllı telefon uygulamas1, orak hücre anemili olgular ve sağlik profesyonelleri arasındaki iletişimi güçlendirerek uzaktan tedavi programlarının erişilebilirliği ve kullanılabilirliği üzerine örnek bir çalışma olmuştur (10)

\subsection{Dikkat eksikliği için mobil uygulama}

Çocukların dikkat eksikliğini değerlendirmek için yapılmış Norogame adlı akıllı telefon uygulamasının amacı; sağlıklı bireylerden uygulama içindeki oyunlarla ilgili reaksiyon süresine ilişkin bir veri tabanı oluşturmak olarak tanımlanmıştır. Elde edilen sonuçlarda dikkat, konsantrasyon ve yaşın tepki hızı ile ilişkili olduğu belirtilmiştir. Mobil uygulama kullanımının amacı hastaların odak, konsantrasyon ve motor becerilerinin gelișimine katkı sağlayarak sağlıklı insanlardan alınan verilerle bir veri tabanı oluşturmaktır. Loleski ve ark. (2018) çalışmalarında aynı zamanda, bu uygulamanın daha da geliştirilerek, dikkat eksikliğinin yanı sıra otizm, hiperaktivite bozukluğu ve konsantrasyon güçlüğü olan çocukların da kullanımına sunmayı hedeflemiştir (11).

\subsection{Solunum sistemi hastalıklarında astım ve yönetimine yönelik uygulamalar}

Astım, çocuklarda görülme oranı yüksek bir solunum sistemi rahatsızlığıdır. ABD'de her 11 çocuktan 1'ine astım tanısı konulmaktadır. Roberts ve arkadașlarının akıllı telefon uygulamasındaki hipotezi; "arkadaş ve aile desteğiyle ilaç tedavisine karşı daha olumlu tutumların teşvik edilmesi, ergen öz yönetim engellerini azaltabilir ve bu da astım kontrolünün yanı 
sıra yaşam kalitesini artırabilir” şeklindedir. Astım tedavi/bakım uygulaması yüklenmiş akıllı cihazlar hastalara verilmiş ve uygulamayı bir hafta boyunca kullanmaları istenmiştir. Araştırma sonunda, iPad ve telefon üzerinden yapılan akran ve bakıcı eğitimlerinin astım hastalarının uyumunu iyileştirdiği ve arttırdığı ifade edilmiştir (12).

Burbank ve arkadaşlarının, 12-17 yaş arasında kronik astımlı ve sık sık astım krizi geçiren çocuklarla yaptıkları çalışmada, çocuklar için özel bir uygulama yapılmış ve sekiz hafta boyunca katılımcıların uygulamaya erişimi sağlanmıştır. Uygulamada eğitimin yanı sıra hastaların semptom girişleri ve yaptıkları ilaç uygulamalarının sisteme girişi sağlanmıştır. $\mathrm{Bu}$ uygulama aracılığı ile çocukların durumu sağlık profesyonellerine iletilmiştir. Sağlık profesyonellerine de anında geri bildirim içeren teşvik edici mesajlarla dönüş yapılmıştır. Katılımcıların \%93'ü mobil uygulamanın astımı kontrol etmede yardımcı olduğunu ve uygulamadan memnun kaldıklarını belirtmiştir. Çalışma, kontrolsüz astımı olan ergenlerde astım kontrolünü ve öz yeterliliği geliştirmede başarı sağlanabileceğini göstermiştir (13).

\subsection{Kemik iliği aspirasyonu öncesi akıllı telefon uygulamasının anksiyete üzerine etkisi}

Çocuklara uygulanan bazı işlem ve prosedürler çocuklarda stres, anksiyete ve korkuya neden olabilmektedir. Bilinmezlik korkusu, çocukların hazırlanmadan uygulamalara alınması ve sağlı personeliyle yaşanan iletişim yetersizliği alternatif çözüm yolları arayışına yol açmıştır. Uygulamada amaç; kemik iliği aspirasyonu yapılacak çocuklarda yetersiz hazırlıktan kaynaklanan kaygı ve endişeyi farmakolojik olmayan yöntemle en aza indirmektir. Tayland'ta kemik iliği aspirasyonu gerçekleştirilen 5 ile 12 yaşlarındaki 60 çocuk örnekleminde yapılan çalışma, tek kör ve randomize kontrollü olarak planlanmıştır. Akıllı telefon uygulamasında, işlemlerle ilgili tüm basamaklar ve kullanılan aletler çocukların yaşına uygun şekilde animasyon, çizgi film ve hekim açıklamaları/anlatımları telefona yüklenmiştir. Ayrıca anksiyeteyi düşürecek oyun, nefes egzersizi ve tıbbi alet bölümü de eklenmiştir. Araştırma sonucunda akıllı telefon uygulamasını kullanan çocukların kaygılarının önemli derecede azaldığı ve anksiyete ölçeği puanlarının da anlamlı derecede düştüğü saptanmıştır. Mobil uygulamanın anksiyeteyi azalttığı, çocuklar ile sağlık çalışanları arasında iş birliğini arttırdığı ve uygulamanın kullanılabilirliğinin yüksek olduğu ifade edilmiştir (14).

\subsection{Preoperatif anksiyetenin azaltılmasında akıllı telefon uygulaması}

Preoperatif dönemde çocuklar ve aileleri önemli derecede anksiyete yaşayabilmektedirler. Yaşanan yüksek orandaki anksiyete vücudun hormon salınımını etkileyerek post dönem iyileşme üzerinde olumsuz etkilere neden olmaktadır. Araştırma, yaşları 1 ile 10 arasında değişen ve çalışma koşullarını sağlayan 120 çocuk ile yürütülmüştür. Çocuklar randomize olarak üç gruba ayrılmıştır. İlk gruba intravenöz midozolam, ikinci gruba akıllı telefon ve son gruba ise düşük doz intravenöz midozalamla akıllı telefon birlikte verilmiştir. Özel bir telefon uygulaması programlanmamış, uygulama seçimi çocuk ve ailesine bırakılmıştır. Uygulamadan beş dakika sonra ve ameliyathaneye girişte modifiye Yale Preoperatif Anksiyete Ölçeği ile çocuklar değerlendirilmiştir. Her üç uygulamada çocukların kaygılarını anlamlı derecede düşürmüştür. Çocukların kaygı düzeylerine bakıldığında en yüksek kaygı midezolam grubunda iken, en düşük kayg1 puanı midezolam ile akıllı telefon kullanan çocuklarda saptanmıştır. Araştırma sonucunda çocukların bireysel özelliklerine göre seçilen akıllı telefon uygulamalarının premedikasyona etkili bir alternatif olabileceği, kaygıyı basit ve etkili bir şekilde çözebileceği ifade edilmiştir (15).

\subsection{Migrenli ergenlerde tedavi uyumunu arttırmaya yönelik telefon uygulaması}

Migren hastalığında, tedavi planına uyulması baş ağrısı sıklığı ve şiddeti gibi semptomların görülmesini engeller. Yapılan araştırmalarda ergenlerin tedavi uyumları \%25 ile \%75 arasında değişmektedir.16 Uygulamanın amacı; mobil uygulama tabanlı bir fizibilite, kabul edilebilirlik ve ön etkinliği test etmek, ilaç saatlerini hatırlatmak, aile katılımını sağlamak, uyumu iyileştirmeyi sağlayan davranışsal tedavi planı oluşturmaktır. Araştırma 13-21 yaş aralığındaki 35 örneklemle yapılmıştır. Çalışma sonucunda hastaların daha uyumlu olduğu ve mobil uygulamaların katkı sağladığı vurgulanmıştır (16).

\subsection{Akıllı telefon tabanlı preterm evde bakım programının} pretermlerin gelişimsel sonuçları üzerine etkisi

Nayak ve ark. (2019) çalışmalarında, üçüncü basamak bir hastanenin yoğun bakım servisine yatırılan 37. gebelik haftasından önce doğan 300 bebeğin ailesi ile evde bakım programı yapmıştır. Randomize olarak aileler iki gruba ayrılmıştır. Müdahale grubuna mobil sağlık temelli preterm evde bakım programı, kontrol grubuna da standart erken bakım hizmeti verilmiştir. Akıllı telefon tabanlı preterm evde bakım 
programının, anneleri hastane ve ev bakımına entegre etme, annelere ve toplum sağlığı çalışanlarına kapsamlı bakım sağlama, pretermlerin uzaktan izlenmesini kolaylaştırma ve yoğun bir program yerine daha yumuşak bir geçiş sağlamada etkin olduğu belirtilmiştir (17).

\section{Sonuç ve Öneriler}

Cep telefonu kullanımının yaygın olması ve mobil cihazların sağlıkla ilgili uygulamalarda kullanılması mobil sağlık uygulamalarının kullanım alanını arttırmaktadır. Mobil sağlık uygulamalarının çocuk sağlığı üzerine kullanımının yeni ve sınırlı olduğu söylenebilir. Ancak PubMed veri tabanı üzerinden son on yılın araştırma sonuçları da göstermektedir ki akıllı telefon uygulamaları sadece çocuk/ergen öznesini değil, bakım verici aileleri ve sağlık profesyonellerini de olumlu yönde etkileme gücüne sahiptir. Uygulamalar ve yürütülen araştırmalar sınırlı olmakla birlikte bunların ortak sonucu mobil sağlk uygulamalarının sağlı profesyonelleri tarafından iyi bir planlama ile yapılandırılıp olgular ve bakım vericilerine sunulduğunda ciddi katkılar sağladığı yönündedir.

Sağlık üzerine programlanmış akıllı telefon uygulamaları kullanımı potansiyel olarak sağlı sonuçlarını ölçebilir. Hastaların kendi kendilerini takip etmelerine olanak tanır. Hasta ve sağlık hizmeti sağlayıcılarıyla doğrudan ve hızlı bir iletişim aracıdır. Tedavi dışı kalma ve sağlık merkezlerine ulaşım imkânı düşük hastalara ulaşma imkânı sağlar. Yüksek riskli hastalığı olan çocuklar ve ergenlerin sağlık yönetimini kolaylaştırabilir. Cep telefonlarının yaygınlığı göz önüne alındığında mobil sağlık uygulamalarının çocuk sağlığını iyileştirme konusunda umut vaat ettiği söylenebilir.

Söz konusu araştırma sonuçları dikkate alındığında pediatri hemşirelerin akıllı telefon uygulamaları üzerine yoğunlaşmaları önerilebilir. $\mathrm{Bu}$ durumun; çocuk/ergen iletişimini kolaylaştıracağı, ulaşım konusunda mesafe engelini ortadan kaldıracağı, çocukların sağlıklı büyüme izlemlerinin, sağlık eğitim ihtiyaçlarının, tedavi, takip ve bakımlarını akıllı telefonlar aracılığ1 ile kesintisiz 24 saat yapılmasına imkân sağlayacağı düşünülmektedir.

Sınırlılıklar: Veri tabanı olarak sadece PubMed veri tabanının kullanılması araştırmanın sınırlılığı olarak düşünülebilir.

Çıkar Çatışması: Çıkar çatışması yoktur.

Finansal Destek: Herhangi bir finansal destek alınmamıştır.
Etik Kurul Onayı: Bu makale derleme türünde yazıldığı için etik kurul onayına gerek yoktur.

\section{Yazarlık Katkısı:}

OI: Analiz ve Yorumlama, Kaynak Taraması, Makalenin Yazımı, Kaynaklar ve Fon Sağlama

Oİ, SŞ: Fikir/Kavram, Tasarım ve Dizayn, Denetleme/Danışmanlık

SŞ, HBY, FY: Eleştirel İnceleme

\section{Kaynaklar}

1. TÜIK. Bilgi Toplumu İstatistikleri. 2017. Erişim Tarihi: 25.03.2020. Erişim Adresi: http://www.tuik.gov.tr/.

2. Fedele DA, Cushing CC, Fritz A, Amaro CM, Ortega A. Mobile health interventions for improving health outcomes in youth a meta-analysis. JAMA Pediatr. 2017; 171(5):461-469.

3. Singh A, Wilkinson S, Braganza S. Smartphones and pediatric apps to mobilize the medical home. J Pediatr. 2014; 165(3):606-610. https://doi.org/10.1016/j.jpeds.2014.05.037.

4. Bates DW, Kuperman GJ, Wang S, Gandhi T, Middleton B. Ten commandments for effective clinical decision support: making the practice of evidence-based medicine a reality. J Am Med Inform Assoc. 2003; 10(6):523-530. https://doi.org/10.1197/jamia.M1370.

5. Jacob E, Stinson J, Duran J, Gupta A, Gerla M, Ann Lewis M. et al. Usability testing of a smartphone for accessing a web-based e-diary for self-monitoring of pain and symptoms in sickle cell disease. J Pediatr Hematol Oncol. 2012; 34(5): 326335. https://doi.org/10.1097/MPH.0b013e318257a13c.

6. Kashgary A, Alsolaimani R, Mosli M, Faraj S. The role of mobile devices in doctor-patient communication: A systematic review and meta-analysis. J Telemed Telecare. 2017; 23(8): 693-700. https://doi.org/10.1177/1357633X16661604.

7. Knab JH, Wallace MS, Wagner RL, Tsoukatos J, Weinger MB. The use of a computer-based decision support system facilitates primary care physicians' management of chronic pain. Anesth Analg. 2001;93(3):712-720. https://doi.org/10.1097/00000539-200109000-00035.

8. Stinson JN, Petroz GC, Tait G, Feldman BM, Streiner D, McGrath PJ, Stevens BJ. e-Ouch: Usability testing of an electronic chronic pain diary for adolescents with arthritis. Clin J Pain. 2006; 22(3):295-305. https://doi.org/10.1097/01.ajp.0000173371.54579.31.

9. Fortier MA, Chung WW, Martinez A, Gago-Masague S, Sender L. Pain buddy: A novel use of m-health in the management of children's cancer pain. Comput Biol Med. 2016; 76: 202-214. https://doi.org/10.1016/j.compbiomed.2016.07.012.

10. Spittaels H, Bourdeaudhuij I. Evaluation of a website-delivered computertailored intervention for increasing physical activity in the general population. $\begin{array}{llll}\text { Elsevier. } & \text { 2007; } & \text { 44(3). } & \text { Retrieved }\end{array}$ https://www.sciencedirect.com/science/article/pii/S0091743506005020.

11. Loleski M, Loleska S, Pop-Jordanova N. Mobile application "neurogame" for assessment the attention, focus and concentration. Prilozi. 2018;38(3):55-62. https://doi.org/10.2478/prilozi-2018-0006.

12. Roberts CA, Geryk LL, Sage AJ, Sleath BL, Tate DF, Carpenter DM. Adolescent, caregiver, and friend preferences for integrating social support and communication features into an asthma self-management app. Journal of Asthma. 2016; 53(9): 948-954. https://doi.org/10.3109/02770903.2016.1171339.

13. Burbank AJ. Mobile-based asthm action plans for adolescents. Journal of Asthma. 2015; 52(6): 583-586. https://doi.org/10.3109/02770903.2014.995307. 
14. Wantanakorn P, Harintajinda S, Chuthapisith J, Anurathapan U, Rattanatamrong PA. New mobile application to reduce anxiety in pediatric patients before bone marrow aspiration procedures. Hosp Pediatr. 2018;8(10):643-650. https://doi.org/10.1542/hpeds.2018-0073.

15. Lee JH, Jung HK, Lee GG, Kim HY, Park SG, Woo SC. Effect of behavioral intervention using smartphone application for preoperative anxiety in pediatric patients. Korean J Anesthesio. 2014; 65(6):508-518. https://doi.org/10.4097/kjae.2013.65.6.508.

16. Ramsey RR. A pilot investigation of a mobile phone application and progressive reminder system to improve adherence to daily prevention treatment in adolescents and young adults with migraine. Cephalalgia. 2018:38(14);2035-2044. https://doi.org/10.1177/0333102418756864.

17. Nayak BS, Lewis LE, Margaret B, Bhat Y, R D’Almeida, J, Phagdol T. Randomized controlled trial on effectiveness of mHealth (mobile/smartphone) based Preterm Home Care Program on developmental outcomes of preterms: Study protocol. J Adv Nurs. 2019; 75(2): 452-460. https://doi.org/10.1111/jan.13879. 